\title{
DECLARATION
}

\begin{abstract}
BY
THE NORTH ATLANTIC TREATY ORGANISATION (NATO)
\end{abstract}

AND

THE GOVERNMENT OF THE ISLAMIC REPUBLIC OF AFGHANISTAN

ON AN ENDURING PARTNERSHIP 


\section{Declaration by \\ the North Atlantic Treaty Organisation (NATO) \\ and the Government of the Islamic Republic of Afghanistan \\ on an Enduring Partnership}

\section{Context}

1. Recognising that stability and prosperity in Afghanistan are of strategic importance to the security of the North Atlantic region, the North Atlantic Treaty Organisation (NATO) and the Government of the Islamic Republic of Afghanistan, after seven years of joint endeavour and sacrifice, believe the time is right to reaffirm their long-term partnership. Afghanistan is increasingly capable of exercising its leadership across the inter-linked domains of governance, development and security. With sustained political, development and humanitarian effort from the United Nations Mission in Afghanistan (UNAMA) and respecting Afghanistan's sovereignty and leadership, the Government of the Islamic Republic of Afghanistan, NATO and its partners in the UN Security Council-mandated International Security Assistance Force (ISAF) are preparing the ground for implementing a process of transition which is consistent with the Framework for Inteqal endorsed by Afghanistan and the International Community at the Kabul conference in July 2010. Transition will further NATO's efforts to help the Afghan people build a durable and just peace and the start of the transition process provides an appropriate opportunity for NATO and the Government of the Islamic Republic of Afghanistan to renew and build a robust, enduring partnership which complements the ISAF security mission and continues beyond it. 


\section{Principles and Purpose}

2. This declaration is intended to be coherent with international efforts, under UN leadership, to support Afghanistan as part of a comprehensive approach. It builds upon the Declaration by the North Atlantic Treaty Organisation and the Government of the Islamic Republic of Afghanistan of 6 September 2006 and existing programmes under the Afghan Cooperation Programme, as most recently endorsed by the North Atlantic Council on 1 March 2010, and the Building Integrity Initiative and NATO Afghan First Policy. It is also intended to be consistent with the provisions of the Afghan National Development Strategy.

3. NATO re-affirms its long-term commitment to a sovereign, independent, democratic, secure and stable Afghanistan that will never again be a safe haven for terrorists and terrorism, and to a better future for the Afghan people. In pursuit of that goal, and recognising Afghanistan as an important NATO partner, NATO intends to provide sustained practical support to Afghan security institutions aimed at:

sustaining and improving their capacity and capability to counter threats to the security, stability and integrity of Afghanistan effectively, and contributing to regional security; and

doing so with full respect for Afghan sovereignty and leadership, in a manner consistent with and supportive of the Afghan constitution and international law and recognising the sacrifices and the ongoing endeavours of the Afghan people for achieving peace.

4. The Government of the Islamic Republic of Afghanistan reaffirms its commitment to:

- $\quad$ actively carry out its security, governance and development responsibilities in a manner consistent with the commitments made at the London Conference of January 2010 and the Kabul Conference of July 2010 such as combating terrorism, strengthening the economy, addressing corruption, 
regional security and economic co-operation and respect for human rights, in particular the rights of women;

- be an enduring partner to NATO and provide NATO with the necessary assistance to carry out its partnership activities within the framework of this declaration; and

recognise the importance and relevance of broader regionally-owned cooperation, coordination and confidence building between Afghanistan and its regional partners, as exemplified in the Istanbul Statement.

\section{NATO and the Government of the Islamic Republic of Afghanistan will} strengthen their consultation on issues of strategic concern.

\section{Content}

6. Effective measures of co-operation should be developed in accordance with Afghan priorities and requirements and the ability of NATO to deliver sustained support. These could include the following :

mechanisms for political and military dialogue;

continuing the use of NATO Trust Funds in support of capacity building of the Government of the Islamic Republic of Afghanistan's security institutions;

- $\quad$ a continuing NATO liaison in Afghanistan to help the implemetnation of this declaration with a common understanding that NATO has no ambition to establish a permanent military presence in Afghanistan or to use its presence in Afghanistan against other nations;

continuation of the NATO Training Mission Afghanistan (NTM-A), reconfigured as necessary, subject to a NAC decision, to meet evolving Afghan security needs;

- an individual programme of additional co-operation activities derived from and incorporating the existing Afghan Co-operation Programme and other current initiatives and priorities, drawing as appropriate upon NATO's menu 
of co-operation tools, and taking into account requests from the Government of the Islamic Republic of Afghanistan. This could include:

- assistance with the development and reform of security ministries and other national institutions;

- helping build professionalism and capacity, and enhancing the capabilities and skill levels in the Afghan security forces including their ability to tackle the threats of terrorism and narcotics trafficking through training and supporting specialised Afghan units; and

- tailored access to NATO courses, institutions and military and civilian expertise.

7. Practical co-operation in accordance with this declaration will:

be approved in accordance with the procedures of NATO and the Government of the Islamic Republic of Afghanistan (in the case of NATO through decisions by nations in the North Atlantic Council);

- be realistic, cost effective and funded in accordance with the procedures of NATO and the Government of the Islamic Republic of Afghanistan;

- be a flexible mix of in country and out of country activities, such as tailored courses, expert exchanges, specialised training and seminars;

be designed to have long-term sustained effect and foster Afghan selfreliance;

avoid duplication of assistance and support being provided by other national, international and non-governmental actors.

\section{Management and Review}

8. NATO and the Government of the Islamic Republic of Afghanistan will commence consultation on their partnership in accordance with the principles in this Declaration. 
9. The co-operation programme resulting from this declaration should be approved between NATO and the Government of the Islamic Republic of Afghanistan on a regular basis through a jointly-owned process.

10. This declaration and the co-operation programme resulting from it should be reviewed at senior political level at intervals of no more than three years. The Government of the Islamic Republic of Afghanistan wishes to initiate a discussion on a Status of Forces Agreement with NATO within the next three years. The proper application of the current Military Technical Agreement will continue to be monitored and reviewed by the Joint Coordinating Body.

11. Non-NATO nations, particularly those participating in ISAF, should have the opportunity and be encouraged to contribute to activities resulting from this declaration including financial contributions, subject to the joint approval of NATO and the Government of the Islamic Republic of Afghanistan. Any bilateral activities between the Government of the Islamic Republic of Afghanistan and any other state is outside the purview of this declaration.

20 November 2010

Anders Fogh Rasmussen

Hamid Karzai

Secretary General of the

President of the

North Atlantic Treaty Organisation

Islamic Republic of Afghanistan 